\title{
TURISMO COM BASE LOCAL. EM BUSCA DE UM QUADRO DE REFERENCIA
}

\author{
Fernanda Sánchez
}

Este breve texto tem um caráter aberto, pois reúne informaçōes acerca de encontro temático de àmbito nacional através de nossa própria leitura do evento, propiciada pela participação nos trabalhos e debates. Realizou-se em Fortaleza Ceará, de 02 a 05 de novembro de 1998, o II ENCONTRO NACIONAL DE TURISMO COM BASE LOCAL, organizado pelo Mestrado em Geografia e pelo Instituto de Estudos, Pesquisas e Projetos - IEPRO, ambos da Universidade Estadual do Ceará - UECE.

O encontro deu continuidade ao primeiro, com formato semelhante, realizado no ano anterior na Universidade de São Paulo - USP. A proposta de continuidade, reforçada agora pela organização deste evento, tem como objetivo criar uma referência nacional centrada na área de estudos da Geografia do Turismo, mas com importantes interlocuções com pensadores provenientes de áreas afins - antropólogos, sociólogos, economistas, arquitetos, entre outros que, junto com os geógrafos, têm contribuido para os estudos do turismo com base local, apontado por diversos autores como alternativa potencialmente sustentável, que se constrói como contraponto à tendència de afirmação do turismo globalizado, predominantemente calcado no modelo sol e praia.

Ao tornar público um conjunto vasto de reflexões de pesquisadores especializados no fenômeno do turismo ou interessados em contribuir com o mesmo, o evento evidenciou a repercus- são que recentemente vem adquirindo o tema no âmbito acadèmico. Com efeito, as discussões mostraram a importância de tão complexo fenômeno em franca expansão, revalorizado pela lógica renovada de produção de mercadorias, lugares luminosos de roteiros globais e imagens sedutoras. Esta produçào dos lugares turisticos precisa ser discutida em suas repercussóes espaciais, mediadas pelas instâncias sociais, culturais, econômicas e políticas, como mostram alguns dos trabalhos apresentados E estas repercussōes parecem ser maiores em paises de economia periférica, o que demanda seriedade e aprofundamento nas pesquisas.

Neste sentido, cabe aplaudir o esforço dos organizadores pois todos os estudiosos do tema central e dos diversos temas correlatos tiveram, neste evento, uma oportunidade de expressão e troca que, certamente, contribuirá para consolidar correntes de pensamento com indicaçóes para serem estendidas em alcance e profundidade. Também é animador vislumbrar a construçào de um campo de afinidade temática e de congregação de pesquisadores, pois, de fato, este evento reafirmou um patamar já construído no primeiro encontro, o que pode ser verificado, em alguns casos mais do que em outros, nas numerosas referēncias e citações do primeiro conjunto de trabalhos, contidas nos que agora foram apresentados. 
Como afirma Balastreri Rodrigues (1997), estudos e publicações sobre o fenômeno do turismo no Brasil, que fujam do viés economicista ou mercadológico, são ainda muito escassos. Entretanto, se pudemos constatar através deste segundo encontro, alguns avanços no sentido do alargamento das preocupações formuladas nos trabalhos, parece-nos que muitos deles ainda não conseguem transcender o formato de estudos de caso e contribuir de forma mais efetiva mediante construçōes teóricas mais consistentes, capazes de criar um quadro de referência para a área.

Se enquanto atividade economica o turismo está em vertiginoso processo de expansão, segundo por indicadores econômicos internacionais, enquanto objeto de estudo, centrado na discussão de suas conseqüências culturais e espaciais, persistem alguns problemas. Referimo-nos a uma ainda considerável produçāo pautada no pragmatismo ou nas exaustivas descriçōes, que, ao nosso ver, pouco ou nada têm a oferecer para a necessária construçào de um campo interpretativo consistente, capaz de avaliar criticamente modelos alternativos e impactos sócio-espaciais dos modelos hegemônicos ou mesmo tendências culturais, políticas e económicas de reorganização do espaço, mediante a implantação de projetos de desenvolvimento do turismo.

Neste sentido, tendo como referencial os trabalhos apresentados, parece-nos que o turismo merece um lugar mais relevante no contexto da reflexão teórica sobre o desenvolvimento. E quando o desenvolvimento ocupa o centro da cena é necessário que os trabalhos explicitem melhor, por um lado, o que entendem por desenvolvimento e, por outro lado, de quais grupos ou segmentos sociais referentes à área de destino turístico se está falando, quando se discute o potencial de desenvolvimento dos projetos. Estes cuidados são importantes, uma vez que parece nào haver resposta universal para a grande questào sempre colocada: o turismo contribui, de fato, para o desenvolvimento local?

É possível verificar, em boa parte dos trabalhos, uma certa leitura compartilhada do "turis- mo alternativo" interpretado como uma saída contraposta às tendências impactantes do ponto de vista cultural e ambiental, e como uma medida compensatória dos efeitos economicamente perversos da globalização. Porém, como afirma Benevides ${ }^{1}$ (1998), se há algumas preocupaçōes comuns a muitos dos trabalhos, quais sejam: preservação ambiental, identidade cultural, geração de ocupaçōes produtivas e de renda, desenvolvimento participativo e qualidade de vida, a proposta de sustentabilidade, entretanto, suscita muitas controvérsias, posto que, muitas vezes, tem um tratamento vago. Assim, alguns trabalhos deixam entrever que a interpretação dada ao turismo alternativo como fator de desenvolvimento local responde a uma ideologia que tangencia ou mesmo se nutre do discurso hegemônico, mais do que propriamente dos interesses das populaçōes locais.

Devido à abrangência desta área de estudos, o encontro foi programado de modo que reunisse conferências de interesse do coletivo de estudiosos bem como doze mesas redondas com temas especificos e aproximadamente cem comunicaçōes livres, também sob organização temática.

As conferências foram de natureza diversa, algumas de caráter descritivo ou informativo acerca de politicas e programas institucionais; outras, mais reflexivas, com aportes conceituais e metodológicos orientados ao entendimento das novas territorialidades no uso turistico do espaço, às implicações sócio-espaciais das novas modalidades de turismo e, finalmente, à construção de elos analíticos entre o tema, mais abrangente, do desenvolvimento local e o tema do turismo.

As mesas redondas tiveram como eixos temáticos: Turismo: do local ao global; Turismo Urbano; Turismo, Paisagem e Ambiente; Turismo Rural; Turismo Religioso: Turismo, Cultura e Patrimônio; Turismo e Processo Educativo; Politicas de Turismo e Regióes; Ecoturismo; Turismo e Ética; Turismo, Natureza e Educação Ambiental; O Turismo na Ótica dos Atores Sociais.

De modo geral, pudemos avaliar que as mesas redondas, que provocaram debates mais pro- 
ficuos, foram aquelas cujos integrantes e interlocutores transcenderam as apresentaçōes de caráter mais descritivo e conseguiram colocar em evidência a própria fragilidade e elasticidade interpretativa do tema "turismo com base local" o que recoloca o desafio de um maior rigor na abordagem das diversas problemáticas e no seu trato teórico-conceitual. Alguns autores deixaram clara a necessidade de adoção deste caminho para o enfrentamento do tema do turismo.

Um comentário final, contudo, não menos importante é mencionar que o encontro foi assumidamente arejado - em seus múltiplos sentidos - e inclusivo pois estimulou bastante interação com o local-sede e seus entornos, propiciando simultaneamente leituras e desfrutes em diversas atividades afins, o que, sem constrangimentos, contribuiu para o sucesso do encontro bem como para os diversos olhares do/no lugar.

Está prevista a publicaçāo em formato de livro das conferências e dos trabalhos apresentados em mesas redondas. Os estudiosos da área ou interessados em conhecer a produção relativa ao evento poderão se dirigir aos coordenadores do mesmo, professores Luiz Cruz Lima, Fábio Perdigão Vasconcelos e Luzia Neide Teixeira Coriolano, do Mestrado em Geografia da UECE.

\section{Nota}

'BENEVIDES, Ireleno. Turismo e Prodetur: dimensōes e olhares em parceria. Fortaleza, UECE/BN, 1998. 